rights and interests of forensic patients is needed. Notwithstanding the recent General Comment issued by the CRPD's Committee, which calls for revisions of insanity defense laws, ${ }^{14}$ this issue raises multiple legal and social challenges that require discussion, not least of them the possibility that such revisions will, in effect, harm-and undermine the rights-of forensic patients. A concerted effort to fathom the needs and rights of forensic patients is needed to ensure that the CRPD's new world is indeed inclusive as it intended to be.

\title{
Addressing Violations of Human Rights in Forensic Psychiatric Institutions: Philosophical and Strategic Debates
}

\section{By Carole J. Petersen}

Michael Perlin and Meredith Schriver vividly describe how forensic psychiatric patients endure horrific conditions, largely abandoned by the general public.' Indeed, if the public pays any attention, it demonizes this group and lobbies for even longer periods of detention. ${ }^{2}$ However, I disagree with the contention that the disability rights movement has also ignored this population. There is disability rights advocacy for detained persons, both in civil and criminal contexts. For example, Disability Rights International (DRI) filed a petition regarding Guatemala's Federico Mora Hospital, which houses both forensic and non-forensic patients. ${ }^{3}$ The Inter-American Commission ordered precautionary measures ${ }^{4}$ and monitoring bodies continue to press the government to improve or close the facility. ${ }^{5}$ DRI also published an extensive report on the Mexican criminal justice system, documenting how individuals are arrested for minor property crimes, deemed "mentally unfit to stand trial," and then detained indefinitely. ${ }^{6}$

The difficulty is that much of the advocacy does not seek improved conditions or even robust safeguards to reduce detention. Rather it focuses on the "higher goals" - full implementation of Articles 12,13, and 14 of the Convention on the Rights of Persons with Disabilities (CRPD), elimination of forensic psychiatric detention, and abolition of any forms of differential treatment in criminal law. While this approach has philosophical appeal, it may not be the best strategy for all persons with disabilities who are accused of crimes.

Article 12 provides that "persons with disabilities enjoy legal capacity on an equal basis with others in all aspects of life" and that states should provide the "support they may

\footnotetext{
${ }^{14}$ Committee on the Rights of Persons with Disabilities, General Comment 1 - Article 12: Equal Recognition Before the Law, CRPD/C/GC/1 (Apr. 11 2014), available at http ://tbinternet.ohchr.org/_layouts/treatybodyexternal/ Download.aspx?symbolno=CRPD/C/GC/l \&Lang=en.

* Professor of Law at the William S. Richardson School of Law and Director of the Matsunaga Institute for Peace and Conflict Resolution, University of Hawaii at Manoa. Email comments to: carolep@hawaii.edu.

'Michael L. Perlin \& Meredith R. Schriver, "You That Hide Behind Walls": The Relationship between the Convention on the Rights of Persons with Disabilities and the Convention Against Torture and the Treatment of Institutionalized Forensic Patients, in Toktuke and Ill-Treatment in Health- Cake Settings: a Compilation 195(American University Center on Humanitarian Law ed., 2013).

${ }^{2}$ The Sentencing Project, Mentally III Offenders in the Criminal Justice System: An Analysis and Prescription 8-9 (Jan. 2002) (the public exaggerates the relationship between psychosocial disabilities and violent behavior and supports prolonged detention).

${ }^{3}$ Disability Rights International, Application for Precautionary Measures in Favor of the 334 People with Mental Disabilities Interned in the Federico Mora Hospital, in Guatemala (Oct. 12, 2012).

${ }^{4}$ Inter-American Commission of Human Rights, Decisions on Precautionary Measures 2012, PM 370/12, available at http://www.oas.org/en/iachr/decisions/precautionary.asp.

${ }^{5}$ Committee Against Torture, Concluding Observations on the Combined Fifth and Sixth Periodic Repurts of Guatemala, CAT/C/GTM/CO/5-6, II 21 (June 21, 2013).

${ }^{6}$ Disability Rights International, The Rights of Persons with Mental Disabilities in the New Mexican Criminal Justice System (June 2013), at http://www.driadvocacy.org/media-gallery/our-reports-publications/.
} 
require in exercising their legal capacity.' However, there is dispute over the effect of Article 12(4), which provides that:

States Parties shall ensure that all measures that relate to the exercise of legal capacity provide for appropriate and effective safeguards to prevent abuse in accordance with international human rights law. Such safeguards shall ensure that measures relating to the exercise of legal capacity respect the rights, will and preferences of the person, are free of conflict of interest and undue influence, are proportional and tailored to the person's circumstances, apply for the shortest time possible and are subject to regular review by a competent, independent and impartial authority or judicial body. The safeguards shall be proportional to the degree to which such measures affect the person's rights and interests.

Many governments interpret Article 12(4) to permit restrictions on legal capacity, so long as they are rare and subject to safeguards. Australia has declared its understanding that the CRPD allows for "fully supported or substituted decision-making arrangements . . . where such arrangements are necessary, as a last resort and subject to safeguards." The UN High Commissioner on Human Rights criticized such interpretations as early as $2009^{7}$ and advised governments to abolish defenses "based on the negation of criminal responsibility because of the existence of a mental or intellectual disability." 8 However, in the absence of practical guidance, many governments simply maintained their pre-existing laws and procedures, including: (1) determinations that certain defendants are "unfit" to stand trial; (2) defenses based upon impairments; and (3) procedures allowing for detention (and/or compulsory treatment) on the ground of disability. ${ }^{9}$

After the Committee on the Rights of Persons with Disabilities (Committee) began reviewing state reports, in 2010 , it concluded that there was "general misunderstanding", regarding the obligation to "shift from the substitute decision-making paradigm to one that is based on supported decision-making." 10 The Committee therefore issued, as its first General Comment, an interpretation of Article 12 that condemns even limited exceptions for substituted decision-making. " Interestingly, however, the document is largely silent on issues of criminal justice. The closest it comes to addressing these issues is in paragraphs 38-40, on the relationship between legal capacity and Articles 13 (access to justice) and 14 (liberty). But even these paragraphs contain no express reference to criminal defendants.

Apparently recognizing its omission, the Committee issued a short "statement" on Article 14 , asserting that "declarations of unfitness to stand trial and the detention of persons based

\footnotetext{
${ }^{7}$ UN High Commissioner for Human Rights, Annual Report: Thematic Study on Enhancing Awareness and Understanding of the Convention on the Rights of Persons with Disabilities, A/HRC/10/48, Il 42 (Jan. 2009).

${ }^{8}$ Id. II 47.

${ }^{9}$ Compulsory treatment is highly controversial. See, e.g., George Szmukler, Rowena Daw \& Felicity Callard, Mental Health Law and the UN Convention on the Rights of Persons with Disabilities, 37 InT'L J. L. \& PsyCHIATRY 245 (2014). Compulsory medical treatment can be a form of torture in certain circumstances, which is prohibited as a jus cogens norm of customary international law, as well as by the CRPD, the CAT, and the International Covenant on Civil and Political Rights.

${ }^{10}$ Committee on the Rights of Persons with Disabilities, General Comment I - Article 12: Equal Recognition Before the Law, CRPD/C/GC/1, (Apr. 11 2014), available at http://tbinternet.ohchr.org/_layouts/treatybodyexternal/ Download.aspx?symbolno=CRPD/C/GC/1\&Lang=en.

${ }^{1}$ Id. III 20-2I.
} 
on that declaration" violate Article $14 .{ }^{12}$ This leaves governments grappling with the question of what specific supports will ensure a fair trial for defendants who, under preCRPD frameworks, were deemed "unfit" to stand trial. Common law jurisdictions consider the participation and understanding of the accused as essential to the adversarial process. The European Court of Human Rights also views "fitness"' as a part of the right to fair trial, guaranteed by Article 6 of the European Convention on Human Rights. ${ }^{13}$ But the traditional test of "fitness" has been whether the defendant has sufficient intellectual capacity to understand the proceedings, which the Committee on the Rights of Persons with Disabilities would certainly condemn.

Governments are also expected to repeal criminal defenses that reference disability. ${ }^{14}$ While the insanity defense is rarely successful, the lesser defense of "diminished responsibility" may be relied upon to lower a murder charge to manslaughter, giving judges more discretion during sentencing. Granted, this discretion can lead to hospital orders, which disability activists may consider worse than prison. But if a judge determines that a defendant who pled "diminished responsibility" presents no danger to the public (which might be the case if a woman killed her abusive spouse after enduring years of domestic violence), she may be released after little or no jail time. Thus, while eliminating this defense might generate formal equality, its substantive impact could be devastating for certain defendants, leading to less, rather than more, personal liberty.

Tina Minkowitz proposes that legal systems abolish disability-based defenses, as well as declarations of unfitness to stand trial, without disadvantaging defendants. ${ }^{15}$ She draws upon the work of Christopher Slobogin who proposed replacing the insanity defense with disabilityneutral defenses that take into account defendants' subjective perceptions. ${ }^{16}$ But it is doubtful that legislatures would ever adopt such vague defenses. It may be more prudent to propose reforms to the current defenses, providing stronger safeguards and more regular review of detention orders for defendants who are either deemed unfit for trial or relied upon disabilitybased defenses. For example, the UK Law Commission's review of "unfitness to plead" is expressly considering how to balance the demands of the CRPD with the requirements of "fair trial" as interpreted by the European Court of Human Rights. ${ }^{17}$ The Australian Law Reform Commission (Australian Commission) has also included, in its December 2014 report, a lengthy discussion of ways to reform the test of "eligibility to stand trial" so as to remove disability-specific language and recognize the role of support mechanisms in enabling certain persons to understand and communicate during a trial. But the Australian

\footnotetext{
12 Committee on the Rights of Persons with Disabilities, Statement on Article 14 of the Convention on the Rights of Persons with Disabilities (Sept. 2014), available at http://www.ohchr.org/EN/NewsEvents/Pages/DisplayNews.aspx? NewsID=15183\&LangID=E. The Committee has also criticized individual governments for maintaining procedures that permit a defendant to be deemed "unfit" to stand trial and subsequently detained. See, e.g., Committee on the Rights of Persons with Disabilities, Concluding Observations on the Initial Report of New Zealand, CRPD/ C/NZL/CO/I, II 33 (Oct. 31, 2014).

${ }^{13}$ SC v United Kingdom, 40 Eur. Ct. H.R. 10 (2005).

${ }^{14}$ UN High Commissioner for Human Rights, Annual Report: Thematic Study on Enhancing Awareness and Understanding of the Convention on the Rights of Persons with Disabilities, A/HRC/10/48, I 47 (Jan. 2009).

${ }^{15}$ Tina Minkowitz, Rethinking Criminal Responsibility from a Critical Disability Perspective: The Abolition of the Insanity/Incapacity Acquittals and Unfitness to Plead and Beyond, 24 Griffith L. Rev. 434 (2014).

${ }^{16}$ Christopher Slobogin, Minding Justice: Laws That Depkive People with Mental. Disability of Life AND LIBERTY (2006), and Christopher Slobogin, Eliminating Mental Disability as a Legal Criterion in Deprivation of Liberty Cases: The Impact of the Convention on the Rights of Persons with Disability on the Insanity Defense, Civil Commitment, and Competency Law, Vanderbilt Pub. L. Research Paper No. 14-23, available at http:// papers.ssrn.com/sol3/papers.cfm?abstract_id=2461279.

${ }^{17}$ Law Commission (UK), Unfitness to Plead (consultation documents available at http://lawcommission.justice.gov.uk/areas/unfitness-to-plead.htm).
} 
Commission stopped short of recommending that all criminal defendants must be eligible to stand trial; nor did it rule out the possibility of detention (subject to regular review) of a person who is deemed ineligible to stand trial. ${ }^{18}$ The Committee on the Rights of Persons with Disabilities may condemn the reforms that are ultimately adopted in the UK and Australia as noncompliant with the CRPD. However, in my view, states parties deserve credit for rolling up their sleeves and grappling with the details of legal capacity in the criminal context. ${ }^{19}$

These governments may seek guidance from the Human Rights Committee (HRC), which recently issued a General Comment interpreting Article 9 (liberty of the person) of the International Covenant on Civil and Political Rights (ICCPR). While calling for revisions to "outdated laws and practices in the field of mental health," it did not conclude that detention is "arbitrary" whenever disability is a factor. It stated that disability "shall not in itself justify a deprivation of liberty but rather any deprivation of liberty must be necessary and proportionate, for the purpose of protecting the individual in question from serious harm or preventing injury to others." 20 The HRC also required that such detention be applied as a measure of last resort, for the shortest appropriate period of time, and accompanied by procedural and substantive safeguards. Although the HRC was criticized for this language by disability rights organizations, ${ }^{21}$ the Working Group on Arbitrary Detention took a similar approach in 2014. It urged states parties to provide judicial review for persons with disabilities who are detained after being declared exempt from criminal responsibility. But it does not appear to interpret Article 14 of the CRPD to preclude all differential treatment in the criminal context. $^{22}$

Finally, we should pay close attention to the Expert Group revising the UN Standard Minimum Rules for the Treatment of Prisoners. Preliminary drafts indicate that it will replace outdated terminology in Rule 82 and accept many (but probably not all) of the recommendations submitted by the Committee on the Rights of Persons with Disabilities and disability rights organizations. As these rules provide the main standards applied in some countries, the revisions could be crucial for individuals detained in forensic psychiatric facilities.

\footnotetext{
${ }^{18}$ Australian Law Reform Commission, Equality, Capacity and Disability in Commonwealih Laws (Al RC Report 124), Ch. 7: Access to Justice: Eligibility to Stand Trial, at https:/www.alrc.gov.au/publications/eligibility-stand-trial.

${ }^{19}$ Australian law reform is particularly important as it tends to influence law reform in the Asia-Pacific region, where disability discrimination is severe. See Carole J. Petersen, The Convention on the Rights of Persons with Disabilities: Using International Law to Promote Social and Economic Development in the Asia Pacific, 35 U. HAw. L. Rev. 831 (2013). For example, Australian law served as a model for Hong Kong's Disability Discri mination Ordinance, which is probably the strongest such law in East Asia. See Carole J. Petersen, A Progressive Law with Weak Enforcement? An Empirical Study of Hong Kong's Disability Law, 25 Disability Stun. Q. 1 (2005)

${ }^{20}$ UN Human Rights Committee, General Comment No. 35 - Article 9 (Liberty and Security of Person), CCPR/ C/GC/35, II 19 (Dec. 16, 2014), available at http://tbinternet.ohchr.org/layouts/treatybodyexternal/TBSearch.asp$x$ ? Lang=en\& Treat $y I D=8 \&$ DocTypeID= 11 (emphasis added).

${ }^{21}$ See World Network of Users and Survivors of Psychiatry (WNUSP) and International Disability Alliance (IDA), Human Rights Committee Disappoints Disability Community; Still Tolerates Mental Health Detention, Press Release (July 24, 2014), available at https://dk-media.s3.amazonaws.com/AA/AG/chrusp-biz/downloads/290157/ WNUSPIDAresponsepara19.pdf.

22 UN Human Rights Council, Report of the Working Group on Arbitrary Detention - A Compilation of National, Regional, and International Laws, Regulations and Practices on the Right to Challenge the Lawfulness of Detention Before Court, A/HRC/27/47, III 46-49 (June 30, 2014), available at http://www.ohchr.org/EN/Issues/Detention/ Pages/Annual.aspx.
} 